Revista Brasil. Bot., V.33, n.1, p.115-129, jan.-mar. 2010

\title{
Morfoanatomia e histoquímica de órgãos reprodutivos de Brosimum gaudichaudii (Moraceae) ${ }^{1}$
}

\author{
EZILDA JACOMASSI ${ }^{2,5}$, ISMAR SEBASTIÃO MOSCHETA ${ }^{3} \mathrm{e}$ \\ SÍLVIA RODRIGUES MACHADO ${ }^{4}$
}

(recebido: 29 de novembro de 2007; aceito: 11 de fevereiro de 2010)

\begin{abstract}
Morphoanatomy and histochemistry of the reproductive organs from Brosimum gaudichaudii (Moraceae)). Brosimum gaudichaudii Trécul, ordinary known as mama-cadela, is an arboreous species common on Brazilian savannah with a great importance on popular food and medicine. The yellow pulp of its fruit is very appreciated by the children because its like a chewing gum. This work presents the morphoanatomical and histochemistry characterization of the inflorescence, fruit and seed of $B$. gaudichaudii. The material were processed by anatomical and ultrastructural usual techniques. The inflorescence is capitate, globose, pedunculate, pendent, predominant by pairs on leaf axilla and covered by thickly hairy peltate bracts. Each inflorescence is composed of several male flowers and one female flower. The male flowers are constituted by a stamen involved by bracteoles. The female flower is constituted by a pistil with an inferior ovary with five carpels, nevertheless just one develops. It is common the presence of two ovules on developed locule, however just one will develop on a seed. The ovule is pendulous, hemianatropous and bitegmic only on the micropilar region. The mature fruit shows: the pulp which is to the comestible region and endocarp; in the seeds the tegument is membranaceous and the embryo without secondary endosperm. The parenchymatic tissue of the pulp presents a lot of intercellular spaces replete of aqueous content. The endocarp is sclerified and shows to be well differentiable on mature fruit. The laticiferous are non-articulated branched with thick walls occurring on inflorescence receptaculum, being abundant on peduncle and in the pulp of the mature fruit and embryo. The phenolic idioblasts are distributed in the inflorescence and fruit.
\end{abstract}

Key words - Anatomy, Brosimum gaudichaudii, fruit, inflorescence, morphology, seed

RESUMO - (Morfoanatomia e histoquímica de órgãos reprodutivos de Brosimum gaudichaudii (Moraceae)). Brosimum gaudichaudii Trécul, popularmente conhecida como "mama-cadela", é uma espécie arbórea comum nos cerrados brasileiros, de grande importância na alimentação e na medicina popular. A polpa amarela dos frutos é muito apreciada pelas crianças por ser semelhante à goma de mascar. Neste trabalho é apresentada a caracterização morfoanatômica e histoquímica da inflorescência, fruto e semente de B. gaudichaudii. O material foi processado segundo técnicas usuais para estudos anatômicos e ultra-estruturais. As inflorescências são captadas, globosas, pedunculadas, pendentes, predominantemente aos pares nas axilas foliares e recobertas por brácteas peltadas densamente pilosas. Cada inflorescência é composta por várias flores masculinas e uma flor feminina. As flores masculinas são constituídas por um estame envolvido por bractéolas. A flor feminina é constituída por um pistilo com ovário ínfero penta-carpelar, entretanto um só lóculo se desenvolve. É comum a presença de dois óvulos no lóculo desenvolvido; entretanto somente um óvulo se desenvolve em semente. O óvulo é pêndulo, hemianátropo e bitegumentado apenas na região micropilar. No fruto maduro, identificam-se: a polpa, correspondente a parte comestível, e endocarpo; na semente, o tegumento é membranáceo e o embrião não apresenta endosperma secundário. O tecido parenquimático da polpa apresenta muitos espaços intercelulares, repletos de conteúdo aquoso. $\mathrm{O}$ endocarpo é esclerificado e encontra-se bem diferenciado no fruto maduro. Os laticíferos são do tipo não-articulado ramificado, com paredes espessas e ocorrem no receptáculo da inflorescência, são abundantes no pedúnculo e na polpa do fruto maduro e no embrião. Os idioblastos fenólicos estão distribuídos na inflorescência e no fruto.

Palavras-chave - anatomia, Brosimum gaudichaudii, fruto, inflorescência, morfologia, semente

\footnotetext{
1. Parte da tese de doutorado da primeira autora, Programa de PósGraduação em Botânica do Instituto de Biociências da Universidade Estadual Paulista Júlio de Mesquita Filho, Campus de Botucatu, SP, Brasil.

2. Universidade Paranaense, Praça Mascarenhas de Moraes, 4282, 87502-210 Umuarama, PR, Brasil.

3. Universidade Estadual de Maringá, Centro de Ciências Biológicas, Departamento de Biologia, Av. Colombo, 5790, Zona 7, 87020-900 Maringá, PR, Brasil.

4. Universidade Estadual Paulista Júlio de Mesquita Filho, Instituto de Biociências, Departamento de Botânica, Campus de Botucatu, Caixa Postal 510, 18618-000 Rubião Júnior, Botucatu, SP, Brasil.

5._Autor para correspondência: ezilda@unipar.br
}

\section{Introdução}

A família Moraceae inclui árvores, arbustos ou ervas, monóicos ou dióicos, com laticíferos abundantemente distribuídos em todas as partes da planta (Romaniuc Neto \& Wanderley 1992). Segundo Cronquist (1981), a família Moraceae apresenta alguns gêneros amplos, como por exemplo, Ficus e Dorstenia com cerca de 500 e 100 espécies, respectivamente. Souza \& Lorenzi (2005) relataram, para esta família, a ocorrência de aproximadamente 50 gêneros e 1.500 espécies, 
predominantemente tropicais e subtropicais, estando representada, no Brasil, por 27 gêneros com cerca de 250 espécies, entre elas Brosimum gaudichaudii Trécul, espécie arbórea popularmente conhecida como mama-cadela, muito comum nos campos de cerrado.

Carauta \& Vianna (1977) relataram para o mesmo gênero a presença de inflorescências globosas em disco convexo, e mais especificamente para B. gaudichaudii, receptáculos andróginos, globosos, longo-pedunculados. Romaniuc Neto \& Wanderley (1992) descreveram para o gênero Brosimum a ocorrência de inflorescências globosas ou obovóides com única flor pistilada imersa na raque carnosa, rodeada por flores estaminadas. Segundo Barroso et al. (2002), o gênero Brosimum apresenta inflorescências capitadas, bissexuadas, cuja superfície externa encontra-se revestida por brácteas circulares, peltadas.

Almeida et al. (1998), referindo-se às espécies úteis do cerrado, relataram que $B$. gaudichaudii é de grande importância na alimentação e na medicina popular. As raízes, cascas e folhas desta planta são amplamente empregadas na medicina popular em várias regiões do país (Lorenzi \& Matos 2002). Entretanto, o uso mais comum e cientificamente comprovado é no tratamento do vitiligo cuja doença caracteriza-se pela despigmentação da pele (Azambuja 1981, Alves et al. 2000). Os princípios ativos responsáveis pela ação contra o vitiligo são duas furanocumarinas: o bergapteno e o psorarelo, ambas as substâncias isoladas das raízes (Pozetti 1969), enquanto nos frutos maduros foi isolado o bergapteno (Pozetti \& Bernardi 1971).

Os frutos maduros de B. gaudichaudii são leitosos e de sabor agradável (Pio Corrêa 1984), amarelos, carnosos, com tamanho médio entre quatro a cinco centímetros de diâmetro e costumam ser colhidos no período de setembro a novembro (Melo et al. 1998) ou, de outubro a janeiro (Lorenzi 1998). Os índios misturam a polpa do fruto com a farinha de mandioca formando uma pasta densa, maleável e adocicada para ser utilizada como alimento (Ferreira 1973). A polpa amarela dos frutos é muito apreciada pelas crianças por ser semelhante à goma de mascar (Matos 1982).

Baseado apenas em características morfológicas, Romaniuc Neto \& Wanderley (1992), na elaboração de chave de identificação para gêneros de Moraceae, denominaram de frutos geralmente drupáceos, utilizando a terminologia drupa globosa para Brosimum glaziovii Taub. Barroso et al. (1999) trataram os frutos do gênero Brosimum como monocárpicos de receptáculo globoso e carnoso que engloba a núcula com semente pêndula, sem endosperma.
Entre os gêneros de Moraceae mais investigados sob o ponto de vista da morfoanatomia reprodutiva estão: Ficus, Morus, Dorstenia e Artocarpus, apresentando características distintas e peculiares, tornando-se difícil a comparação com outros gêneros da família. Desta forma, considerando a importância medicinal e alimentícia de B. gaudichaudii, somado a escassez de literatura, neste trabalho é apresentada a caracterização morfoanatômica e histoquímica de órgãos reprodutivos desta espécie.

\section{Material e métodos}

Local de estudo - Amostras de flores, frutos e sementes foram obtidas de exemplares de $B$. gaudichaudii ocorrentes na Estação Ecológica do Cerrado, localizada no município de Campo Mourão ( $24^{\circ} 18^{\prime}$ S, $23^{\circ} 55^{\prime} \mathrm{N}, 630$ m), região noroeste do Estado do Paraná. Ramos férteis foram herborizados e depositados no Herbário "Irina Delanova Gemtchujnicov" sob o número 24171, do Departamento de Botânica, UNESP, Campus de Botucatu (BOTU). O clima de Campo Mourão, segundo classificação de Köppen, é do tipo Cfa - clima subtropical úmido, com média térmica no mês mais quente superior a $22{ }^{\circ} \mathrm{C}$ e no mês mais frio, inferior a $18^{\circ} \mathrm{C}$. A precipitação média, por ano, encontra-se entre $1.200 \mathrm{e}$ $1.600 \mathrm{~mm}$, com tendência de concentração das chuvas no verão (Maack 1981, IAPAR 1994).

Amostragem - Foram amostrados cinco exemplares de uma mesma população. As inflorescências foram coletadas no início do desenvolvimento, sem abertura das flores. Das inflorescências adultas, foram amostradas flores masculinas, femininas e região mediana do pedúnculo. Os frutos com sementes foram estudados em três estágios de desenvolvimento: jovem, imaturo e maduro, isto é, com $1 \mathrm{~cm}$, $1,5 \mathrm{~cm}$ e $2 \mathrm{~cm}$ de diâmetro, respectivamente. O pedúnculo do fruto foi amostrado somente na fase madura.

Estudo morfoanatômico - As amostras das inflorescências e dos frutos com sementes foram imersas em FAA em etanol $50 \%$ durante 48 horas e, posteriormente, transferidas para o etanol 70\% (Johansen 1940). Parte do material foi seccionado à mão livre, com auxílio de lâminas de barbear, e também com micrótomo de rotação. As amostras seccionadas à mão livre foram clarificadas em hipoclorito de sódio $20 \%$, posteriormente lavadas em água destilada, coradas com safranina e azul de astra (Gerlach 1969) e montadas em lâmina com gelatina glicerinada. Para a confecção de lâminas permanentes, as amostras fixadas foram desidratadas em série etílica e incluídas em resina hidroxi-etil-metacrilato (Gerrits 1991). As secções obtidas ao micrótomo de rotação, com $7 \mu \mathrm{m}$ de espessura, foram coradas com hematoxilina de Erlich (Johansen 1940). Apenas o pedúnculo foi corado com azul de toluidina $0,05 \%$ em tampão fosfato $\mathrm{pH} 4,3$ (O’Brien et al. 1964). Posteriormente, as lâminas foram montadas em Permount. 
As fotomicrografias foram obtidas por captura de imagem pelo programa Image Pro-Plus, versão 4.0. As escalas referentes às ilustrações foram obtidas através de lâmina micrométrica nas mesmas condições ópticas utilizadas para cada caso.

Testes histoquímicos - Para os testes histoquímicos das inflorescências e dos frutos com sementes, cortes de material fresco foram tratados com: Sudan IV para detecção de lipídios totais (Johansen 1940); solução aquosa de cloreto férrico a $10 \%$ para marcação de compostos fenólicos (Johansen 1940); solução aquosa de vermelho de rutênio a 0,02\% para identificação de polissacarídeos diversos e pectinas (Jensen 1962); solução de lugol (iodo + iodeto de potássio) para amido e alcalóides (Johansen 1940); solução de azul mercúrio de bromofenol para proteínas (Mazia et al. 1953). Os controles para cada teste seguiram as indicações dos respectivos autores. Lâminas temporárias foram montadas em glicerina.

Microscopia eletrônica de varredura(MEV)-Acaracterização morfológica das superfícies das inflorescências e dos frutos foi complementada com análise ao microscópio eletrônico de varredura segundo a técnica de Robards (1978). Para isso, as amostras foram fixadas em glutaraldeído 2,5\% (tampão fosfato $0,1 \mathrm{M} \mathrm{pH} \mathrm{7,3} \mathrm{por} 24$ horas); pós-fixadas em tetróxido de ósmio $1 \%$, no mesmo tampão; desidratadas em série alcoólica; secadas em ponto crítico com $\mathrm{CO}_{2} \mathrm{e}$ metalizadas com camada de $10 \mathrm{~nm}$ de ouro. O material foi observado ao microscópio eletrônico de varredura SEM 515 da Philips, em $20 \mathrm{kV}$, e documentação com filme Technical Pan Asa 25.

\section{Resultados e discussão}

Morfologia e anatomia da inflorescência - No início do desenvolvimento, as inflorescências são popularmente denominadas "cápsulas de inflorescência". Neste estágio não apresentam pedúnculo diferenciado, são recobertas por brácteas foliáceas densamente pilosas (figuras 1-2) e estomatíferas. Dois tipos de tricomas estão presentes na superfície externa das brácteas: tectores unicelulares pontiagudos e glandulares peltados (figura 2). As inflorescências desenvolvidas são capitadas, globosas, pedunculadas, pendentes, ocorrem predominantemente aos pares nas axilas foliares (figuras 3-4) e são recobertas por brácteas peltadas (figuras 5-6). Estas brácteas apresentam epiderme unisseriada com compostos fenólicos, parênquima repleto de idioblastos fenólicos e traços vasculares (figura 6). Tais características coincidem com àquelas descritas por Barroso et al. (2002), que descreveram para o gênero Brosimum a ocorrência de inflorescências capitadas, bissexuadas, cuja superfície externa encontra-se revestida por brácteas circulares, peltadas. Carauta \& Vianna (1977) também relataram para o mesmo gênero a presença de inflorescências globosas em disco convexo, e mais especificamente para B. gaudichaudii, receptáculos andróginos, globosos, longo-pedunculados, o que foi exatamente observado neste estudo para as flores de B. gaudichaudii.

$\mathrm{Na}$ fase de antese, as brácteas ainda sobrepostas umas às outras (figura 5) permitem a exposição das flores masculinas, constituídas de apenas um estame circundado por bractéolas foliáceas (figuras 6-7), onde ocorre a emergência apenas das anteras (figura 8), distribuídas por toda a superfície da inflorescência. Os autores Carauta \& Vianna (1977), Romaniuc Neto \& Wanderley (1992), Barroso et al. (1999, 2002), quando se referiram às inflorescências de Brosimum, relataram apenas ocorrência de brácteas e não de bractéolas. O estame apresenta filete curto, conectivo amplo e duas tecas (figura 9) com deiscência rimosa (figura 8). Durante a maturação dos grãos de pólen, cada teca contém dois sacos polínicos bem desenvolvidos com numerosos micrósporos (figura 10). A parede da antera, junto aos sacos polínicos, é formada pela epiderme unisseriada, endotécio de células maiores, duas camadas médias e pelo tapete secretor (figura 11). $\mathrm{Na}$ antera madura a epiderme torna-se delgada e rompida. Esta situação é descrita por Mariath et al. (2006) como característica típica para as plantas em geral, em que a epiderme torna-se fina na maturidade da antera, podendo ocorrer colapso, compressão, distensão ou ruptura de suas células e, neste caso, o endotécio pode então constituir a camada mais externa da antera.

Além das flores masculinas, a inflorescência é composta por apenas uma flor feminina, coincidindo com a descrição relatada por Romaniuc Neto \& Wanderley (1992), quando descreveram para o gênero Brosimum a ocorrência de inflorescências com uma única flor pistilada rodeada por flores estaminadas. A flor feminina é representada por um pistilo com estigma bífido, estilete que se projeta durante a antese para exposição do estigma e ovário ínfero imerso no receptáculo carnoso bem desenvolvido (figura 12), composto por epiderme unisseriada e parênquima com muitos idioblastos fenólicos (figura 6) e laticíferos (figura 13).

O ovário apresenta cinco carpelos, apenas um se desenvolve e os outros quatros são atrofiados, sem óvulos, podendo ser reconhecidos pelos lóculos vestigiais (figura 14). É comum a presença de dois óvulos no lóculo desenvolvido, entretanto somente um se desenvolverá em semente (figura 14). O óvulo é pêndulo do tipo hemianátropo com funículo curto (figura 15) e calaza bem desenvolvida. Os tegumentos interno e externo ficam restritos à região micropilar (figura 16). Corner (1976) descreveu para Moraceae óvulos mais ou 

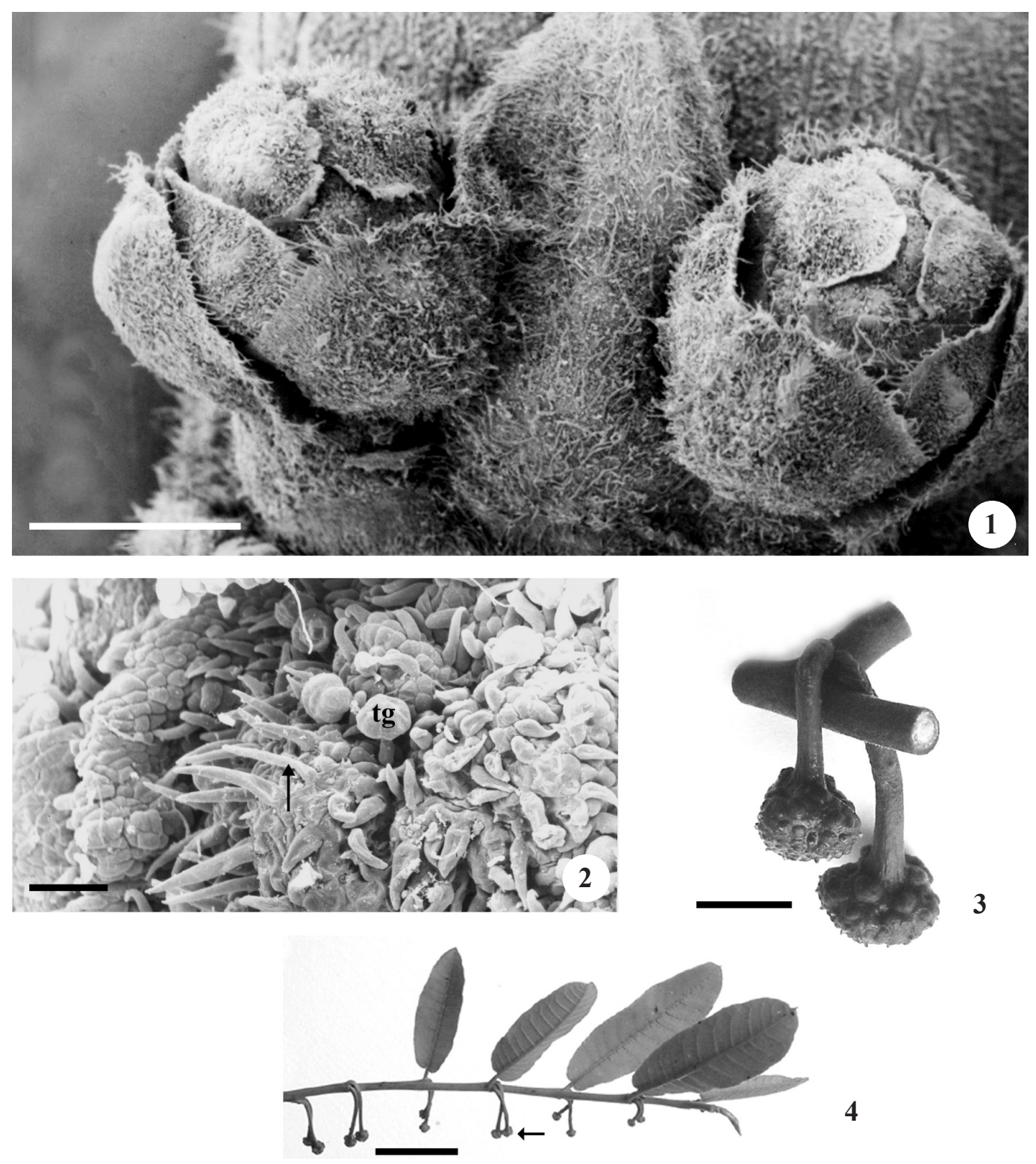

Figuras 1-4. Brosimum gaudichaudii. Vista frontal em MEV das inflorescências em estágio inicial (1-2) e inflorescências desenvolvidas (3-4). 1. Duas inflorescências recobertas por brácteas pilosas. 2. Tricomas tectores (seta) e tricomas glandulares. 3. Par de inflorescências. 4. Ramo com inflorescências aos pares (seta) nas axilas foliares. ( $\operatorname{tg}=$ tricoma glandular). Barra $=940 \mu \mathrm{m}(1), 53 \mu \mathrm{m}(2), 0,5 \mathrm{~cm}(3), 3 \mathrm{~cm}(4)$.

Figures 1-4. Brosimum gaudichaudii. Scanning electron micrographs front view of early stage (1-2) and developed inflorescences stage (3-4). 1. Two inflorescences covered by hairy bracts. 2. Non-glandular (arrow) and glandular trichomes. 3. A pair of inflorescences. 4. Branch with inflorescences in pairs (arrow) in the leaf axils. (tg $=$ glandular trichome). Bar $=940 \mu \mathrm{m}(1)$, $53 \mu \mathrm{m}(2), 0,5 \mathrm{~cm}(3), 3 \mathrm{~cm}(4)$.

menos anátropos, suspensos, solitários, bitegumentados e crassinucelados. Esta descrição pode ser aplicada para B. gaudichaudii.

Morfologia e anatomia do fruto jovem e da semente Nesta fase de maturação, o fruto formado pelo desenvolvimento do receptáculo carnoso apresenta-se morfologicamente muito semelhante à inflorescência, com maior volume, resultante da multiplicação celular. As camadas celulares mais internas à polpa formam o endocarpo e apresentam arranjo denso, sem a presença de espaços intercelulares (figura 18). Com 

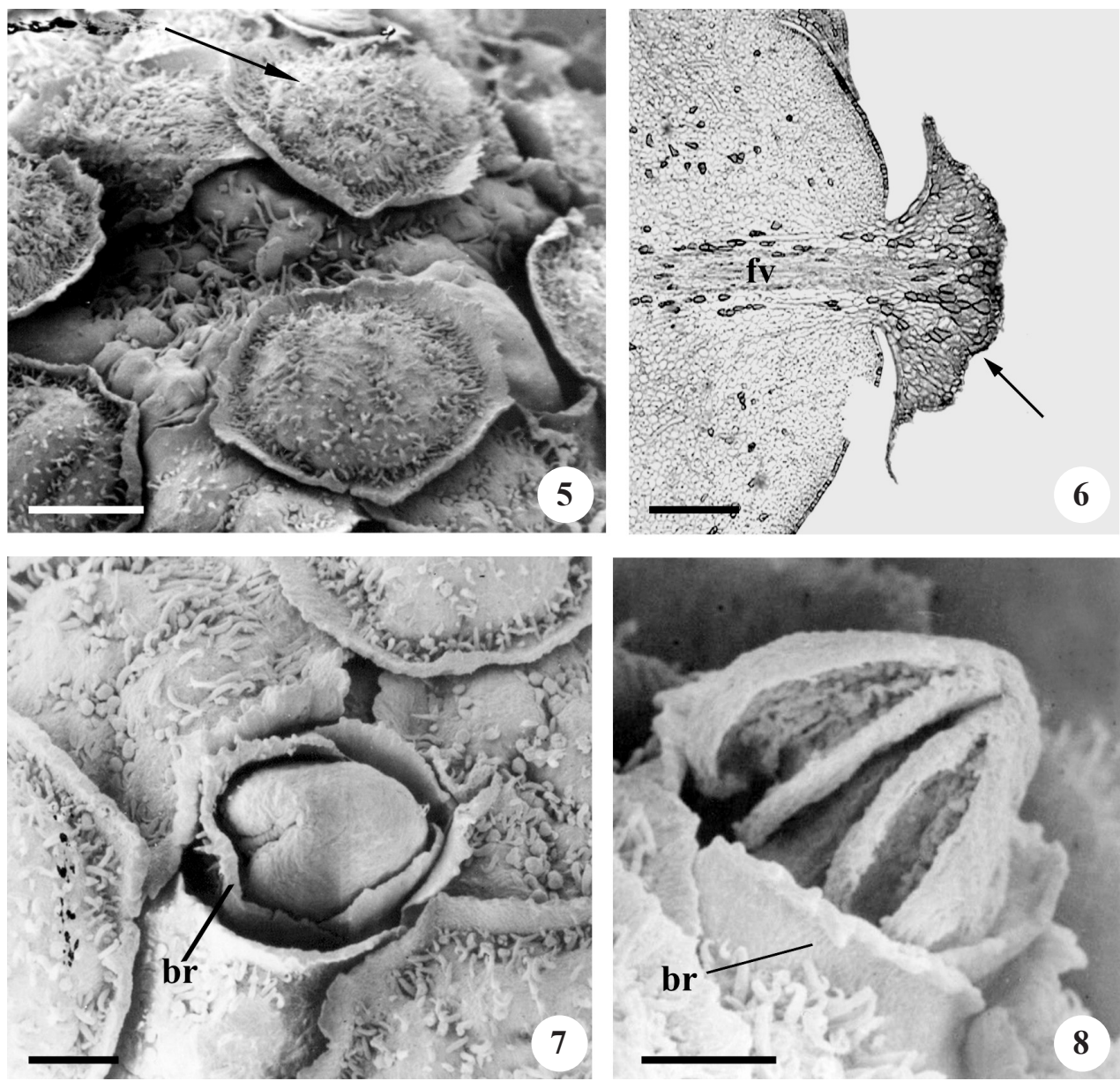

Figuras 5-8. Inflorescência de Brosimum gaudichaudii recoberta por brácteas peltadas. Vista frontal em MEV (5, 7-8) e secção longitudinal (6). 5. Superfície da inflorescência. 6. Bráctea peltada (seta). 7. Flor masculina com anteras fechadas. 8. Flor masculina com deiscência rimosa. (br = bractéola; $\mathrm{fv}=$ feixe vascular). Barra $=430 \mu \mathrm{m}(5), 100 \mu \mathrm{m}(6), 186 \mu \mathrm{m}(7), 123 \mu \mathrm{m}(8)$.

Figures 5-8. Brosimum gaudichaudii inflorescence covered by peltate bracts. Scanning electron micrographs front view $(5,7-8)$ and longitudinal sections (6). 5. Inflorescence surface. 6. Peltate bract (arrow). 7. Male flower with closed anthers. 8. Male flower with longitudinal dehiscence. $(\mathrm{br}=$ bracteole; $\mathrm{fv}=$ vascular bundle). $\mathrm{Bar}=430 \mu \mathrm{m}(5), 100 \mu \mathrm{m}(6), 186 \mu \mathrm{m}(7), 123 \mu \mathrm{m}(8)$.
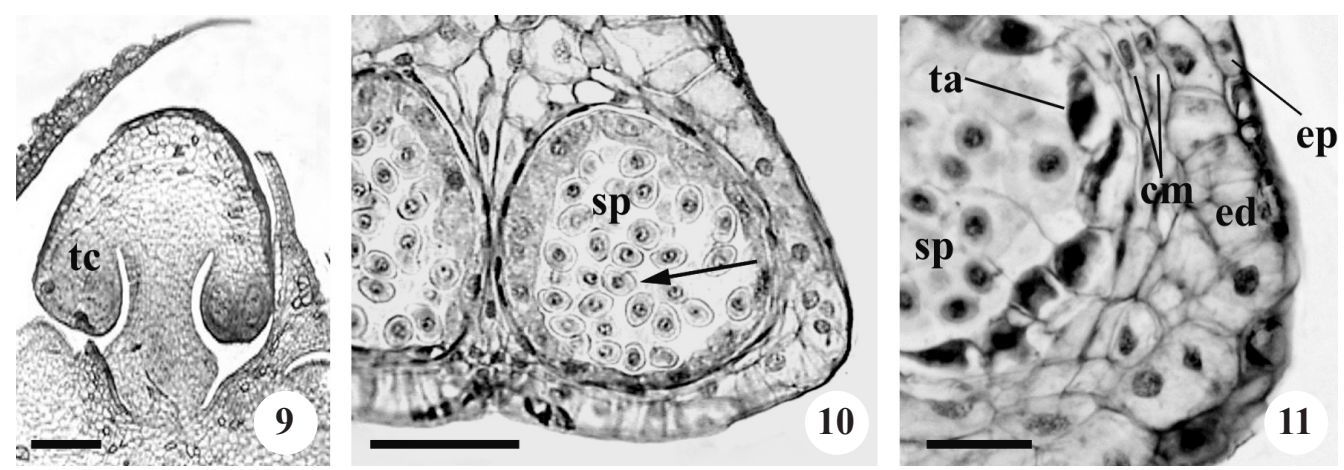

Figuras 9-11. Flor masculina de Brosimum gaudichaudii. 9. Estame. 10. Antera com micrósporos (seta). 11. Parede da antera. (cm $=$ camada média; ed = endotécio; $\mathrm{ep}=$ epiderme; $\mathrm{sp}=$ saco polínico; ta = tapete; tc $=$ teca $)$. Barra $=50 \mu \mathrm{m}(9,10), 15 \mu \mathrm{m}(11)$.

Figures 9-11. Brosimum gaudichaudii male flower. 9. Stamen. 10. Anther with microspores (arrow). 11. Anther wall. $(\mathrm{cm}=$ middle layer; ed = endothecium; $\mathrm{ep}=$ epidermis; $\mathrm{sp}=$ pollen sac; ta = tapetum; tc = theca). $\mathrm{Bar}=50 \mu \mathrm{m}(9,10), 15 \mu \mathrm{m}(11)$. 

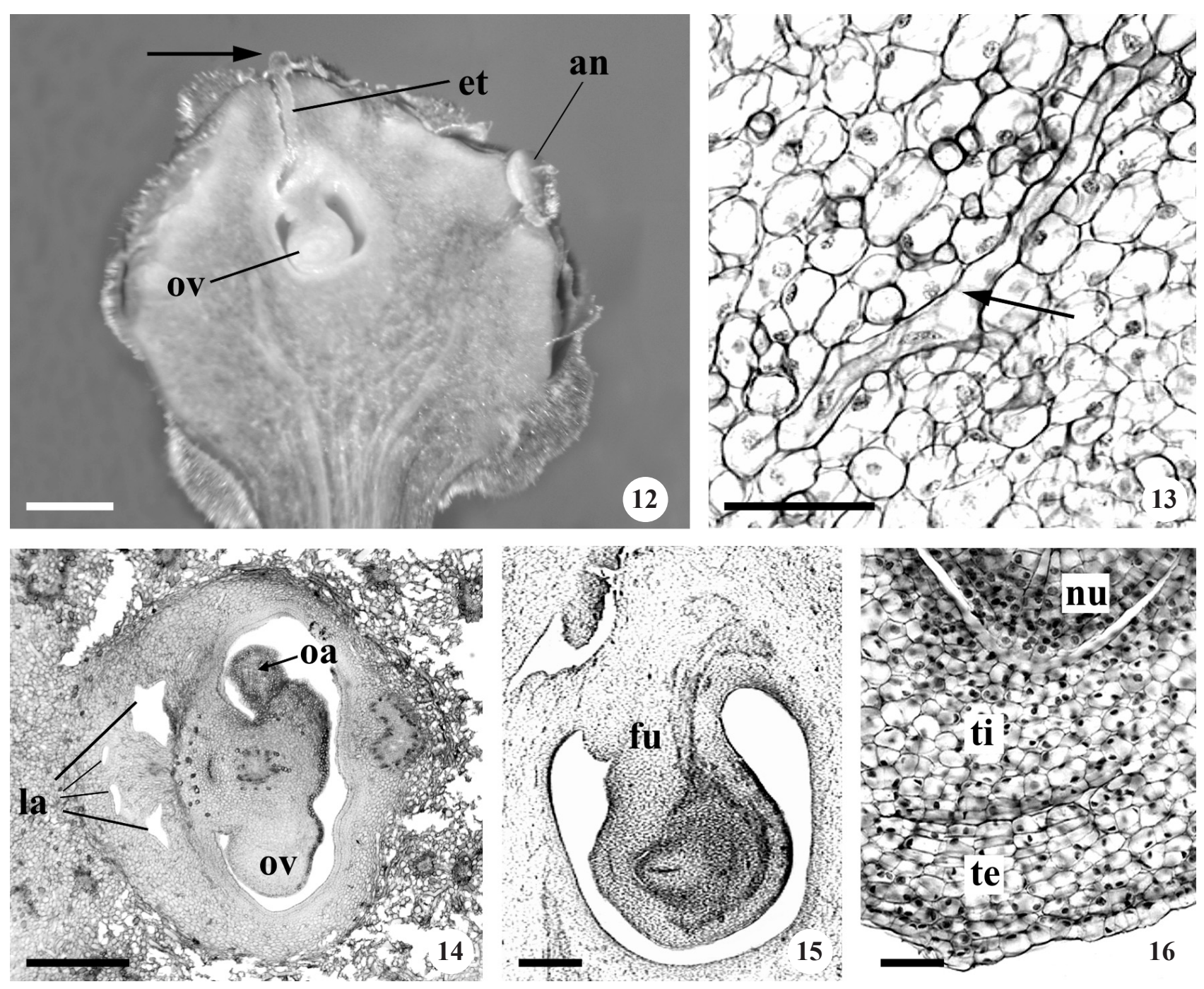

Figuras 12-16. Inflorescência de Brosimum gaudichaudii em secções transversais (13 e 14) e longitudinais (12, 15 e 16). 12. Ovário ínfero com estigma exposto na superfície (seta). 13. Receptáculo com laticífero (seta). 14. Ovário com apenas um óvulo desenvolvido. 15. Óvulo hemianátropo. 16. Região micropilar. $(a n=$ antera; et = estilete; fu = funículo; la = lóculo atrofiado; $\mathrm{nu}=$ nucelo; oa $=$ óvulo atrofiado; ov = óvulo; te = tegumento externo; $\mathrm{ti}=$ tegumento interno). Barra $=1 \mathrm{~mm}(12), 50 \mu \mathrm{m}$ $(13,16), 500 \mu \mathrm{m}(14), 250 \mu \mathrm{m}(15)$.

Figures 12-16. Cross-sections (13 and 14) and longitudinal sections (12, 15 and 16) of Brosimum gaudichaudii inflorescence. 12. Inferior ovary with exposed stigma on the inflorescence surface (arrow). 13. Receptacle with laticifer (arrow). 14. Ovary with one developed ovule. 15. Hemianatropous ovule. 16. Micropylar region. $($ an $=$ anther; et $=$ style; fu $=$ funiculus; $\mathrm{la}=$ atrophied locule; $\mathrm{nu}=$ nucellus; oa $=$ atrophied ovule; ov $=$ ovule; te $=$ outer integument; $\mathrm{ti}=$ inner integument). $\operatorname{Bar}=1 \mathrm{~mm}(12), 50 \mu \mathrm{m}(13,16), 500 \mu \mathrm{m}(14), 250 \mu \mathrm{m}(15)$.

o desenvolvimento da semente, a paquicalaza, não multiplicativa, praticamente mantém o número de camadas celulares presentes no óvulo. A espessura da paquicalaza na região basal é maior e mais vascularizada, bem como o número de idioblastos fenólicos (figura 17). Segundo a descrição de Corner (1976) para as formas das sementes, $B$. gaudichaudii pode ser enquadrada no tipo paquicalazal. O mesmo autor descreve a formação da paquicalaza que é comumente bem vascularizada nas espécies estudadas de diferentes famílias. No entanto, a semente de $B$. gaudichaudii não apresenta vascularização em toda a sua extensão, limitando-se apenas à região basal. A epiderme externa do tegumento da semente é composta por células de paredes espessadas com impregnação de compostos fenólicos (figuras 18-19). Pode ocorrer impregnação destes compostos também 
na camada subepidérmica (figura 19). Nesta fase de desenvolvimento o endosperma celularizado, bastante evidente (figura 17), permanece íntegro na região mais externa (figura 20), enquanto na região interna, junto ao embrião em crescimento, notam-se indícios de alteração estrutural (figura 21) devido à absorção. Os idioblastos fenólicos são observados especialmente no tegumento da semente (figuras 17, 19-20).

Morfologia e anatomia do fruto imaturo e maduro - O fruto imaturo (figura 22) apresenta-se morfologicamente muito semelhante ao fruto maduro (figura 23). No fruto

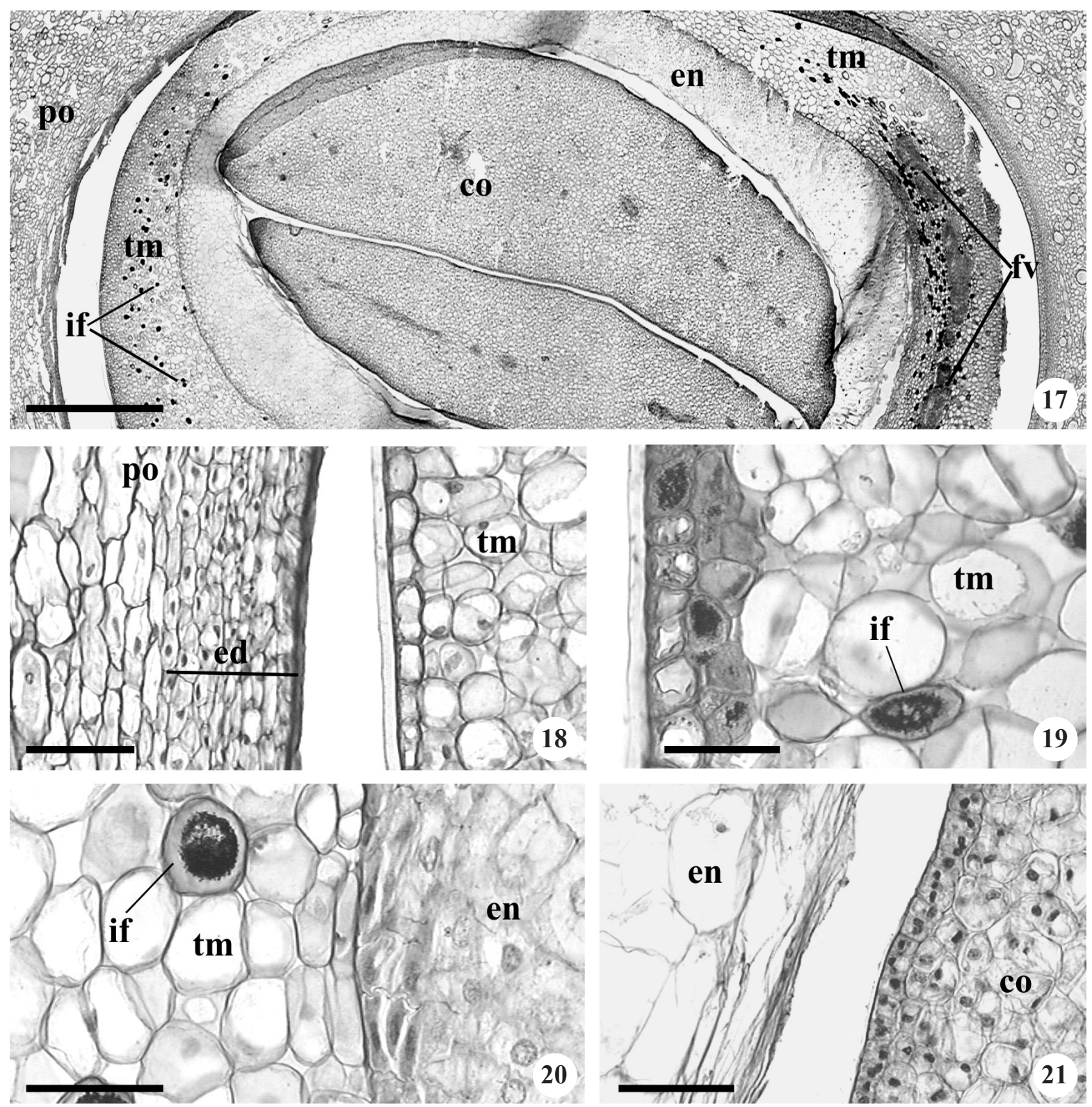

Figuras 17-21. Fruto jovem de Brosimum gaudichaudii em secções tranversais. 17. Semente. 18. Polpa e tegumento. 19. Região externa do tegumento. 20. Região interna do tegumento e endosperma. 21. Endosperma e cotilédone. (co = cotilédone; ed $=$ endocarpo; $\mathrm{en}=$ endosperma; $\mathrm{fv}=$ feixe vascular; if $=$ idioblasto fenólico; $\mathrm{po}=$ polpa; $\mathrm{tm}=$ tegumento $)$. Barra $=800 \mu \mathrm{m}$ (17), $50 \mu \mathrm{m}(18,19,20,21)$.

Figures 17-21. Cross-sections of Brosimum gaudichaudii young fruit. 17. Seed. 18. Pulp and seed coat. 19. Outer region of the seed coat. 20. Inner region of the seed coat and endosperm. 21. Endosperm and cotyledon. $(c o=$ cotyledon; ed $=$ endocarp; en $=$ endosperm; $\mathrm{fv}=$ vascular bundle; if $=$ phenolic idioblast; $\mathrm{po}=$ pulp; $\mathrm{tm}=$ coat $) . \mathrm{Bar}=800 \mu \mathrm{m}(17), 50 \mu \mathrm{m}(18,19,20,21)$. 
imaturo, a polpa, latescente, resultante do receptáculo carnoso desenvolvido, é de coloração esverdeada. No fruto maduro, além do aumento de diâmetro, a polpa (figura 24) adquire coloração amarelo-ouro ou amarelo-alaranjado. A polpa constitui a parte comestível quando madura, e apresenta abundância de laticíferos com grande produção de látex. As brácteas permanecem pouco alteradas com perda parcial da pilosidade (figura 25). Barroso et al. (1999) relataram para o gênero Brosimum um receptáculo carnoso, latescente,
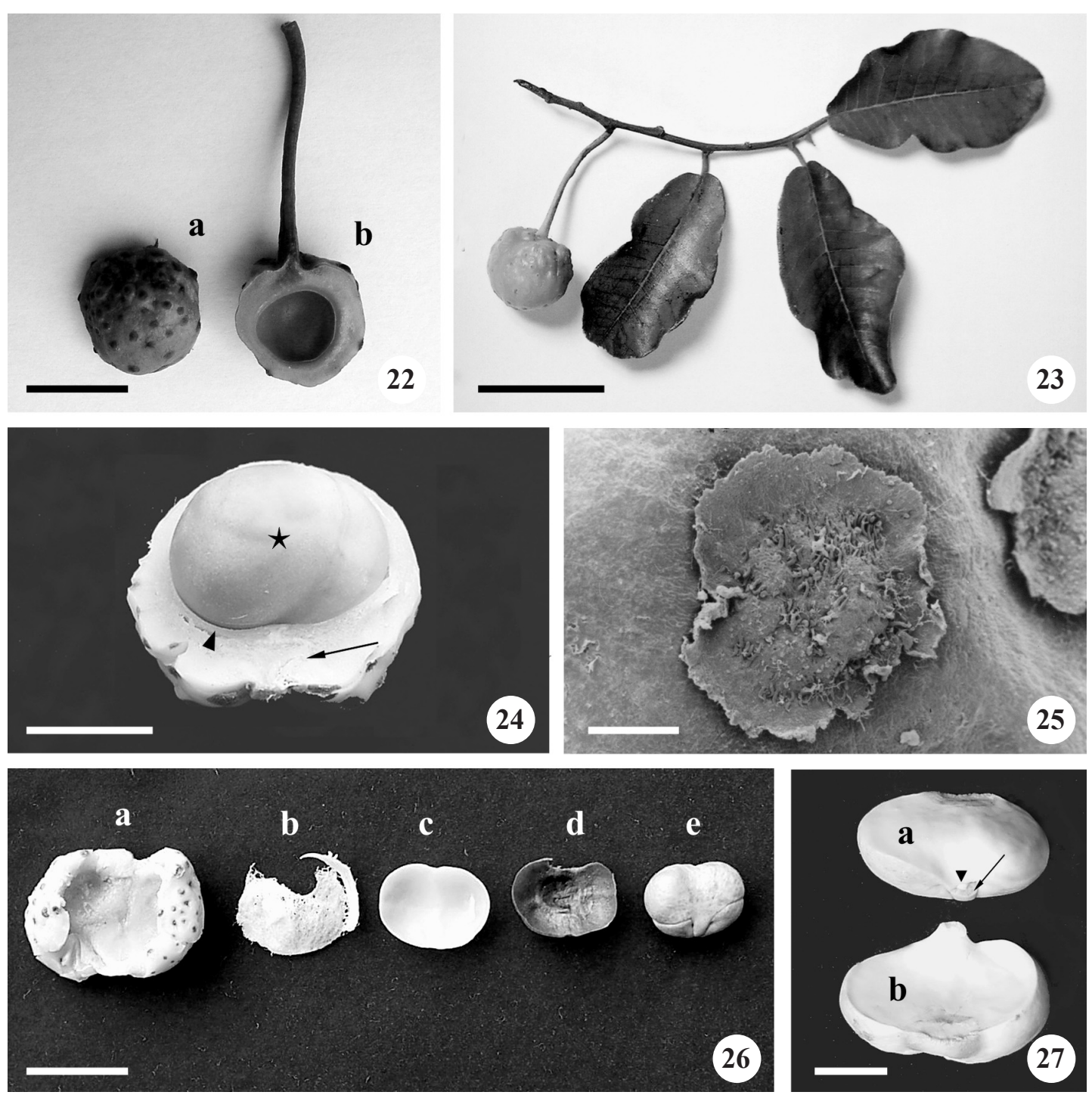

Figuras 22-27. Fruto e semente de Brosimum gaudichaudii em visão macroscópica (22-24 e 26-27) e em MEV (25). 22. Fruto imaturo com brácteas na superfície externa (a) e pericarpo em corte (b). 23. Ramo com fruto maduro. 24. Fruto maduro evidenciando polpa (seta), endocarpo (ponta de seta) e semente (estrela). 25. Brácteas do fruto maduro. 26. Fruto maduro ( $\mathrm{a}=$ polpa, $\mathrm{b}=$ porção mais vascularizada da polpa, $\mathrm{c}=$ endocarpo, $\mathrm{d}=$ tegumento, $\mathrm{e}=$ embrião). 27 . Cotilédones carnosos assimétricos com face abaxial convexa, adaxial plano-convexa (a) ou plano-côncava (b), plúmula pouco evidente (ponta de seta) e eixo embrionário (seta). Barra $=1 \mathrm{~cm}(22,24,27), 4 \mathrm{~cm}(23), 284 \mu \mathrm{m}(25), 2 \mathrm{~cm}(26)$.

Figures 22-27. Macroscopic view (22-24 and 26-27) and scanning electron micrographs (25) of Brosimum gaudichaudii fruit and seed. 22. Immature fruit with bracts on the outer surface (a) and cross-section of the pericarp (b). 23. Branch with ripe fruit. 24. Ripe fruit showing pulp (arrow), endocarp (arrow head) and seed (star). 25. Bracts of the ripe fruit. 26. Ripe fruit $(\mathrm{a}=$ pulp, $\mathrm{b}=$ vascularized region of the pulp, $\mathrm{c}=$ endocarp, $\mathrm{d}=$ coat, $\mathrm{e}=$ embryo). 27. Fleshy asymmetric cotyledons with convex abaxial surface, plane-convex adaxial surface (a) or plane-concave surface (b), unclear plumule (arrow head) and axial embryo (arrow). Bar $=1 \mathrm{~cm}(22,24,27), 4 \mathrm{~cm}(23), 284 \mu \mathrm{m}(25), 2 \mathrm{~cm}(26)$. 
amarelo, com polpa adocicada e comestível, recoberto por bractéolas que protegiam as flores masculinas no estágio de inflorescência. No entanto, conforme verificado neste trabalho, em B. gaudichaudii tratam-se de brácteas peltadas (figura 25), aquelas que recobriam a inflorescência (figura 1).

Dissecando-se o fruto maduro, individualizam-se partes distintas: polpa, porção vascularizada, endocarpo, e a semente com tegumento membranáceo e embrião (figura 26). O embrião apresenta dois cotilédones carnosos, curto-peciolados, curvos e assimétricos em relação à forma e tamanho. A face abaxial dos dois cotilédones é convexa enquanto a face adaxial é plano-convexa em um e plano-côncava em outro (figura 27). É comum o desenvolvimento diferenciado dos cotilédones onde um deles pode apresentar redução de até $1 / 3$ do tamanho, corroborando Barroso et al. (1999), que mencionaram a presença de cotilédones iguais ou desiguais entre si para o gênero Brosimum. A reserva dos cotilédones de $B$. gaudichaudii é composta de amido, além de proteína e lipídio, igualmente encontrada por Balerone et al. (2002) nesta espécie. O eixo hipocótiloradicular é curto e ligeiramente achatado, a plúmula é inconspícua, sem diferenciação evidente dos primórdios foliares (figura 27). O embrião preenche todo o volume da semente, sendo classificado segundo Martin (1946), como total e invaginado.

No fruto imaturo, a polpa (figura 28) não evidencia grandes mudanças anatômicas comparadas ao fruto jovem. A epiderme externa apresenta cutícula espessa e células com conteúdo fenólico (figura 29). Ainda neste estágio ocorrem divisões celulares em diversos planos. Nas camadas mais internas há predominância de divisões periclinais que irão determinar, juntamente com a epiderme interna, a constituição do endocarpo esclerificado (figura 30). Os feixes vasculares, mais abundantes na região interna da polpa, são do tipo anficrival (figura 31). Eames \& MacDaniels (1947) relataram que pequenos feixes anficrivais, comuns nas pteridófitas, podem ocorrer em flores, frutos e óvulos de angiospermas. As células do tegumento da semente do fruto imaturo (figuras 32-33) tornam-se colapsadas e comprimidas, possivelmente em decorrência da compressão exercida pelo crescimento do embrião e resistência do endocarpo esclerificado. Há dúvidas se as sementes de espécies de Moraceae podem ser consideradas como exotestais (Corner 1976). Em $B$. gaudichaudii esta dificuldade é confirmada uma vez que o tegumento não apresenta camada mecânica distinta. $\mathrm{O}$ endosperma, que no fruto jovem já apresentava sinais de alteração estrutural, é totalmente consumido ainda neste estágio (figura 32), exceto resquícios na região da calaza em estágio do fruto imaturo (figura 33 ).

No fruto maduro a epiderme não mais contém compostos fenólicos e o tecido parenquimático da polpa apresenta muitos espaços intercelulares (figuras 34-36), repletos de conteúdo aquoso e maiores na região mais interna (figura 35). O parênquima da polpa é equivalente ao descrito para frutos carnosos, que segundo Eames \& MacDaniels (1947) é composto por células com paredes delgadas mais ou menos túrgidas com fluidos, algumas contendo taninos ou mucilagens. Neste estágio de desenvolvimento, as brácteas permanecem estruturalmente pouco modificadas em relação à inflorescência, inclusive com idioblastos fenólicos (figura 37). O mesocarpo, ricamente vascularizado, é formado também por aproximadamente seis camadas de células parenquimáticas e o endocarpo esclerificado encontra-se bem diferenciado formado por aproximadamente seis camadas compactas de macroesclereídes (figura 38) que constitui o envoltório protetor mecânico do diásporo. Uma pequena porção da polpa permanece aderida ao endocarpo quando a parte comestível é retirada. O tegumento da semente permanece comprimido (figura 39) e constitui a camada adjacente que envolve o embrião.

Barroso et al. (1999) trataram os frutos do gênero Brosimum como monocárpicos de receptáculo globoso e carnoso que engloba a núcula com semente pêndula, sem endosperma. Romaniuc Neto \& Wanderley (1992), quando utilizaram características morfológicas em chave de identificação para gêneros de Moraceae, denominaram de frutos geralmente drupáceos, utilizando a terminologia drupa globosa para Brosimum glaziovii. Embora tenham sido realizadas observações a respeito da estrutura anatômica de B. gaudichaudii, torna-se difícil o enquadramento deste tipo de fruto na classificação convencional, uma vez que a descrição para drupa, segundo Font Quer (1985), se refere ao fruto originado de uma flor e não de uma inflorescência, geralmente monocárpico e com ovário súpero. Como exemplo pode-se citar Prunus, que apesar de pertencer a uma outra família (Rosaceae), trata-se de uma drupa típica, como descrito anatomicamente por Roth (1977). Em B. gaudichaudii, o ovário é ínfero concrescido com o receptáculo da inflorescência e o endocarpo, embora rígido, é delgado e não concrescido com a semente. Também o termo núcula, utilizado por Barroso et al. (1999) na descrição do fruto de Brosimum, não se enquadra perfeitamente por se tratar de uma inflorescência e não de flor isolada.

Brosimum gaudichaudii também não se encaixa no amplo sistema de classificação proposto por Spjut (1994) que descreveu alguns tipos que são adequados 

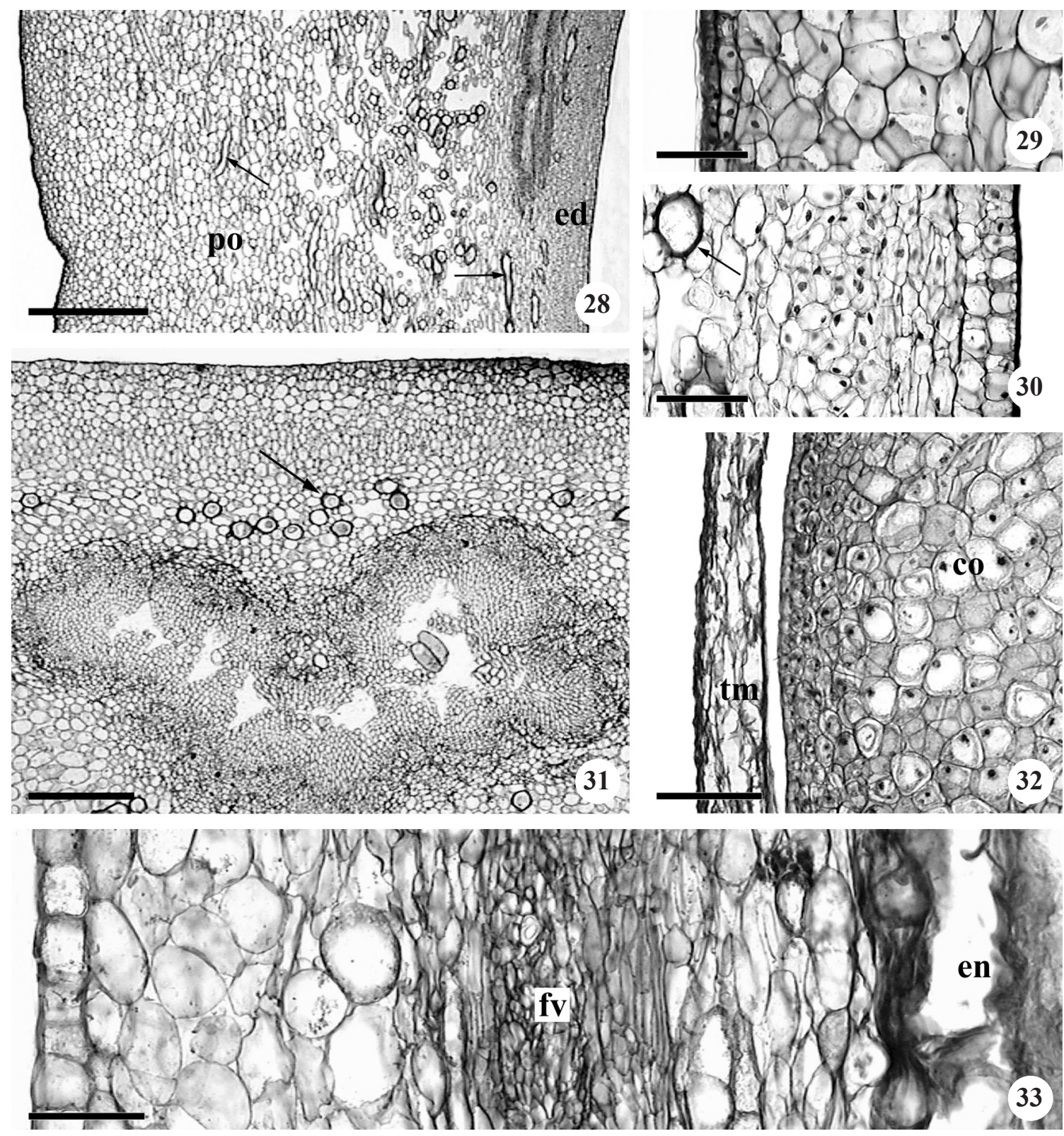

Figuras 28-33. Fruto imaturo de Brosimum gaudichaudii em secções tranversais. 28. Polpa com laticíferos (setas). 29. Região externa da polpa. 30. Pericarpo com laticíferos (seta). 31. Feixe vascular anficrival e laticíferos (seta) na polpa. 32. Tegumento e cotilédone. 33. Tegumento e endosperma. $(\mathrm{co}=$ cotilédone; $\mathrm{ed}=$ endocarpo; $\mathrm{en}=$ endosperma; $\mathrm{fv}=$ feixe vascular; $\mathrm{po}=$ polpa; $\mathrm{tm}=$ tegumento). Barra $=500 \mu \mathrm{m}(28), 50 \mu \mathrm{m}(29,30,33), 200 \mu \mathrm{m}(31), 100 \mu \mathrm{m}(32)$.

Figures 28-33. Cross-sections of Brosimum gaudichaudii immature fruit. 28. Pulp with laticifers (arrows). 29. Outer region of the pulp. 30. Pericarp with laticifers (arrow). 31. Amphicrival vascular bundle and laticifers (arrow) in the pulp. 32. Coat and cotyledon. 33. Coat and endosperm. $(\mathrm{co}=$ cotyledon; $\mathrm{ed}=$ endocarp; $\mathrm{en}=$ endosperm; $\mathrm{fv}=$ vascular bundle; $\mathrm{po}=\mathrm{pul} p ; \mathrm{tm}=$ coat $)$. Bar $=500 \mu \mathrm{m}$ (28), $50 \mu \mathrm{m}$ (29, 30, 33), $200 \mu \mathrm{m}$ (31), $100 \mu \mathrm{m}$ (32).

para outros gêneros de Moraceae, como sicônio para Ficus, pseudodrupa para Pseudolmedia e sorose para Morus. Souza \& Rosa (2005) descreveram para Sorocea bonplandii (Baill.) Burger, Lanjow \& Boer (Moraceae) o fruto do tipo pomáceo que não é adequado para $B$. gaudichaudii, pois diferentemente, $S$. bonplandii é originado de apenas uma flor.

Enfim, levando-se em consideração que o receptáculo que envolve o frutéolo é da inflorescência e não de uma flor, o fruto de $B$. gaudichaudii pode ser enquadrado 


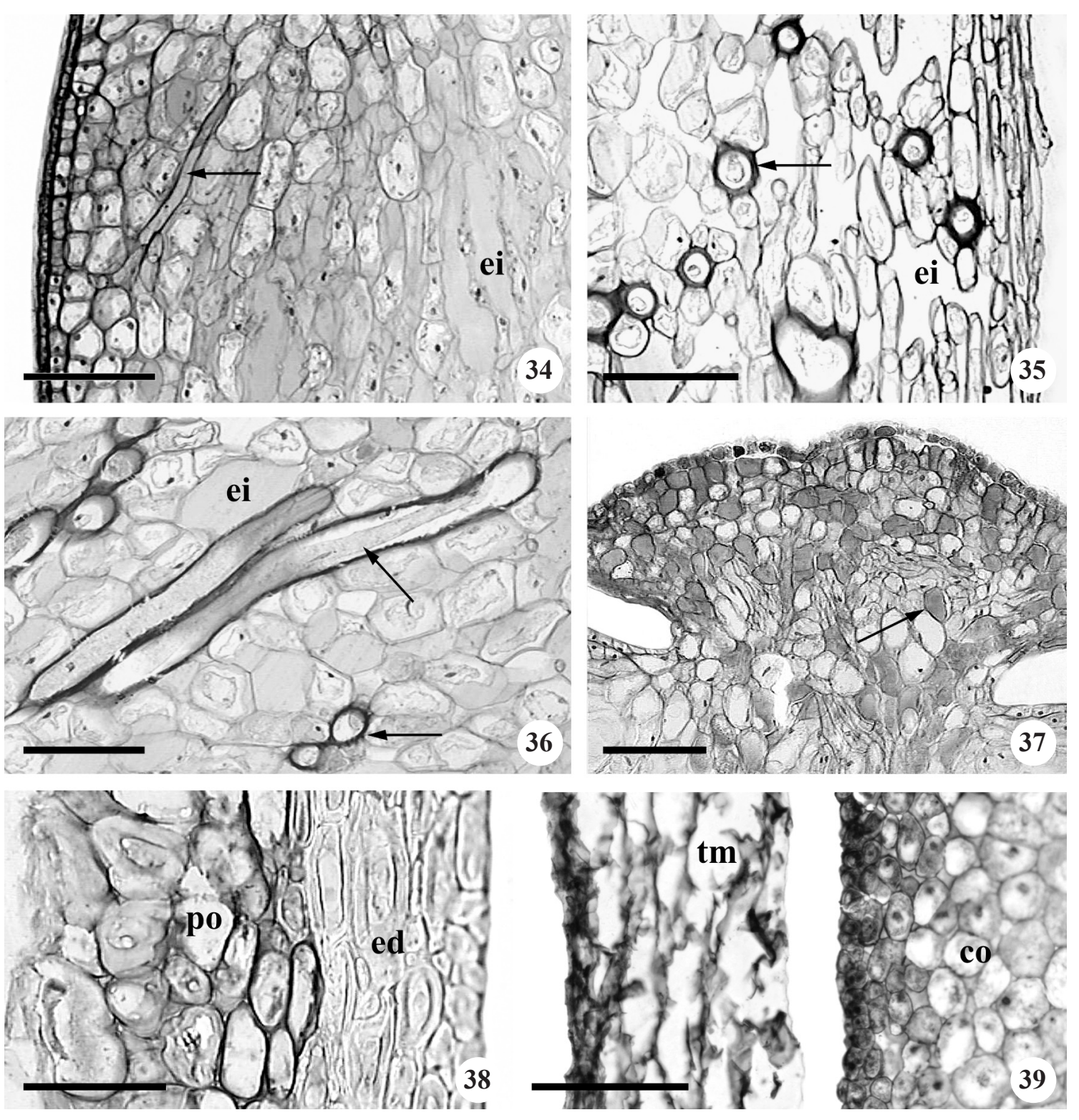

Figuras 34-39. Fruto maduro de Brosimum gaudichaudii em secções tranversais. 34. Polpa com laticífero (seta). 35. Região interna da polpa com laticíferos (seta). 36. Laticíferos da polpa (seta). 37. Bráctea peltada com idioblastos fenólicos (seta). 38. Endocarpo e camadas adjacentes da polpa. 39. Tegumento e cotilédone. ( $c$ o cotilédone; ed $=$ endocarpo; ei $=$ espaço intercelular; po $=$ polpa; $\mathrm{tm}=$ tegumento). Barra $=100 \mu \mathrm{m}(34,35,36,37,39), 50 \mu \mathrm{m}(38)$.

Figures 34-39. Cross-sections of Brosimum gaudichaudii ripe fruit. 34. Pulp with laticifer (arrow). 35. Inner region of the pulp with laticifer (arrow). 36. Pulp's laticifers (arrow). 37. Peltate bracts with phenolic idioblasts (arrow). 38. Endocarp and adjacent layers of the pulp. 39 . Coat and cotyledons. $(c o=$ cotyledons; $\mathrm{ed}=$ endocarp; $\mathrm{ei}=$ intercellular space; $\mathrm{po}=\mathrm{pulp} ; \mathrm{tm}$ $=$ coat $)$. Bar $=100 \mu \mathrm{m}(34,35,36,37,39), 50 \mu \mathrm{m}(38)$.

como múltiplo, segundo Souza (2003), monocárpico, com frutéolo do tipo nuculânio, pois somente um lóculo se desenvolve.

Os laticíferos são do tipo não-articulado ramificado, com paredes espessas (figuras 35-36) e estão localizados no receptáculo da inflorescência (figura 13), na polpa do fruto (figuras 28, 30, 31, 34-36), no embrião, no pedúnculo da inflorescência e do fruto (figura 40). Os laticíferos presentes em Moraceae são enfatizados por vários autores. Solereder (1908) e Metcalfe \& Chalk (1950) relataram a presença de laticíferos para a maioria dos gêneros de Moraceae, entre eles, Brosimum. Esau 
(1965) e Fahn (1969) descreveram a presença de laticíferos não-articulados, que podem ramificar-se ou não, para várias famílias, entre elas, Moraceae. Cronquist (1981) enfatizou os laticíferos presentes no tecido parenquimático do caule e folha com conteúdos extraordinariamente diversos em diferentes membros da família Moraceae. Veenendaal \& Outer (1990) descreveram a ocorrência de laticíferos não-articulados ramificados em todos os órgãos vegetativos de Morus nigra L. discutindo que em Moraceae não há presença de laticíferos articulados.

Anatomia do pedúnculo da inflorescência e do fruto maduro - A estrutura anatômica do pedúnculo da inflorescência (figuras 40-41) e do fruto maduro (figuras 42-43) não apresenta grandes diferenças, exceto pela
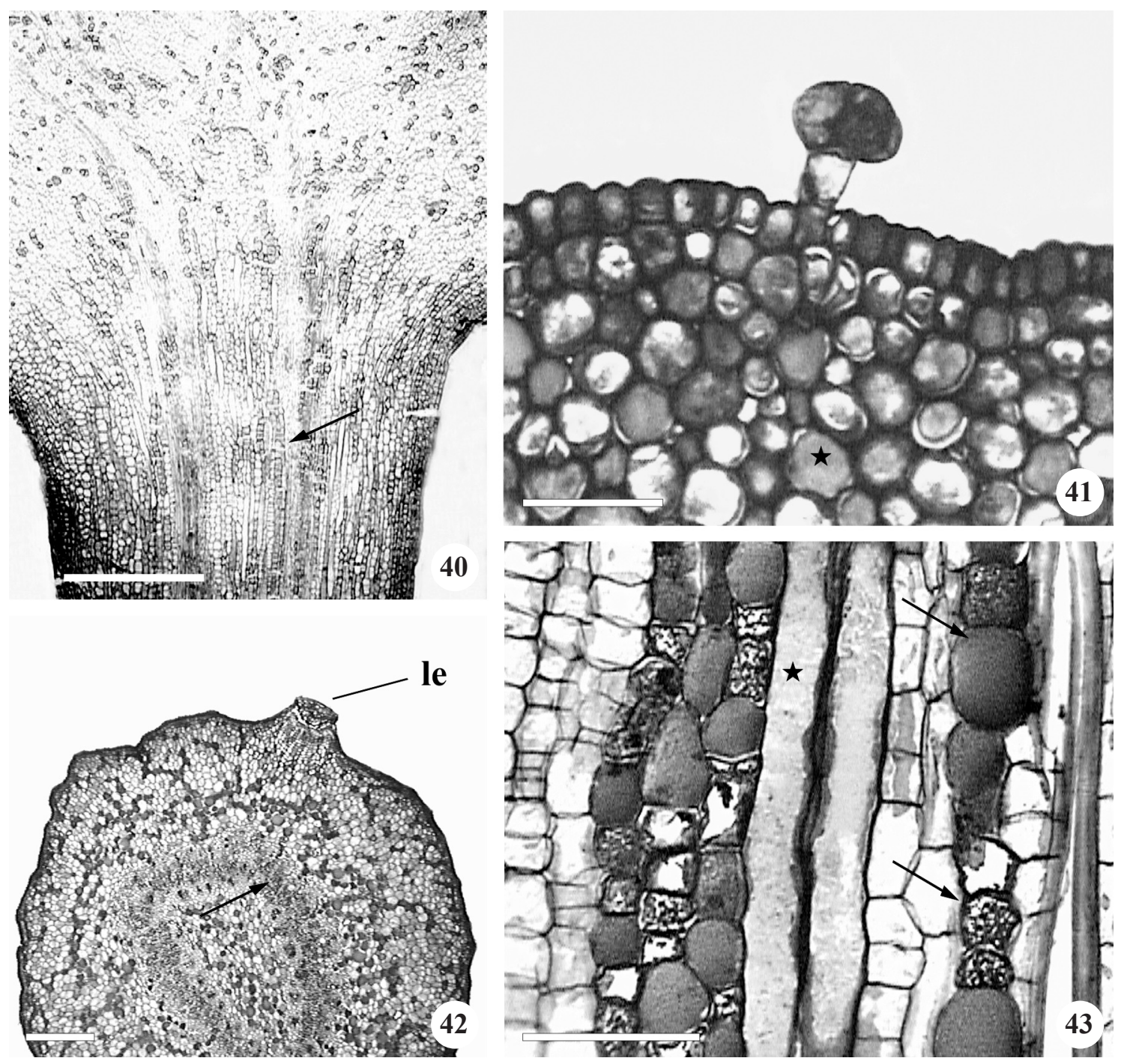

Figuras 40-43. Pedúnculo da inflorescência (40 e 41) e do fruto maduro (42 e 43) de Brosimum gaudichaudii. 40. Secção longitudinal com numerosos idioblastos fenólicos (seta). 41. Epiderme unisseriada com tricoma glandular peltado e idioblastos fenólicos (estrela), em secção tranversal. 42. Secção transversal com lenticela e idioblastos fenólicos (seta). 43. Laticífero (estrela) e idioblastos fenólicos (setas) na região cortical, em secção longitudinal. (le = lenticela). Barra = 500 $\mu \mathrm{m}(40), 50$ $\mu \mathrm{m}(41), 300 \mu \mathrm{m}(42), 100 \mu \mathrm{m}$ (43).

Figures 40-43. Peduncle of inflorescence (40 and 41) and ripe fruit (42 and 43) of Brosimum gaudichaudii. 40. Longitudinal section with numerous phenolic idioblasts (arrow). 41. Cross-section of uniseriate epidermis with peltate glandular trichome and phenolic idioblasts (star). 42. Cross-section with lenticel and phenolic idioblasts (arrow). 43. Longitudinal section of the laticifer (star) and phenolic idioblasts (arrows) in the cortical region. (le = lenticel). Bar $=500 \mu \mathrm{m}(40), 50 \mu \mathrm{m}(41), 300 \mu \mathrm{m}$ (42), $100 \mu \mathrm{m}$ (43). 
baixa densidade de tricomas tectores e glandulares e pela presença de lenticelas no pedúnculo do fruto maduro. A epiderme é unisseriada com células repletas de compostos fenólicos (figura 41); os tipos de tricomas são os mesmos observados nas inflorescências. A região cortical é compreendida por aproximadamente 20 camadas de células parenquimáticas. O sistema vascular está distribuído em círculo com uma medula parenquimática (figura 42). Calotas de fibras gelatinosas ocorrem externamente ao floema (figura 44). Estas fibras apresentam substâncias altamente higroscópicas na camada parietal interna, atuando como possíveis reservatórios de água, como descrito por Paviani (1978). Esse mesmo autor já sugeria em 1974, tal função para as fibras gelatinosas do xilopódio de Plathymenia reticulata Benth., espécie de cerrado. Os laticíferos (figura 43) e os idioblastos fenólicos (figuras 40-43) estão presentes no córtex, medula e floema.

Histoquímica - Os grãos de amido estão presentes no pedúnculo da inflorescência e do fruto, especialmente na região cortical, bem como em células parenquimáticas da polpa do fruto (figura 45). São abundantes nos cotilédones, onde apresentam formas e tamanhos variados com predominância de formas esféricas e truncadas (figura 46).

O cloreto férrico, empregado para identificação de compostos fenólicos, mostrou reação fortemente positiva, especialmente no parênquima, inclusive no parênquima xilemático, do pedúnculo da inflorescência (figuras 40-41) e do fruto (figuras 42-43, 47), além do tecido parenquimático que compõe as brácteas do fruto (figura 37), sendo moderadamente positiva em células parenquimáticas da região periférica da polpa do fruto e negativa para a semente.

O sudan IV, utilizado para identificação de lipídios em geral, mostrou reação positiva na inflorescência e no fruto estando bem evidenciados na cutícula e nos laticíferos destes órgãos, bem como na forma de gotículas em células parenquimáticas (figura 48).

Vermelho de rutênio, utilizado para a identificação de polissacarídeos, indicou reação fortemente positiva
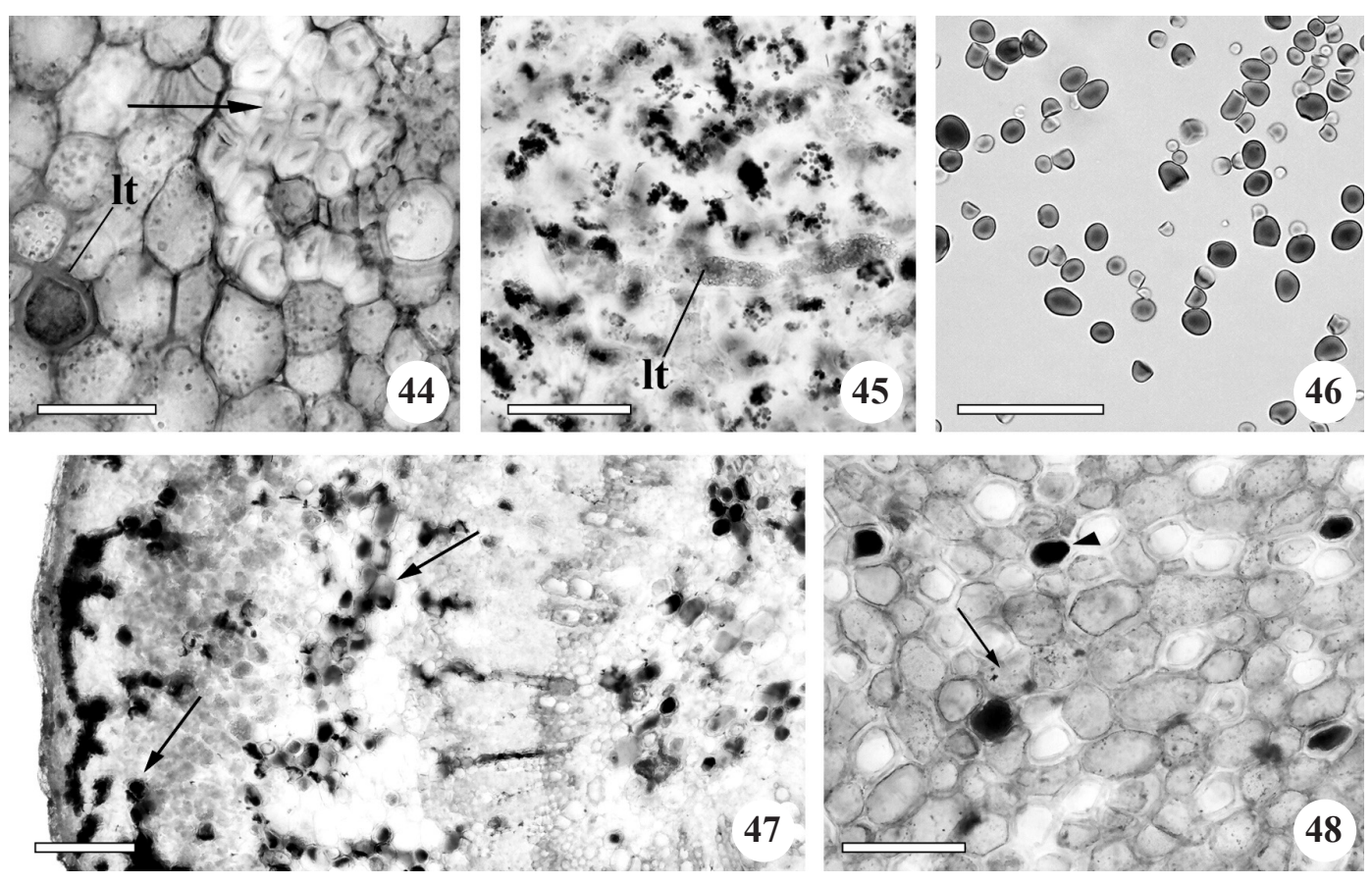

Figuras 44-48. Fruto de Brosimum gaudichaudii submetido aos testes histoquímicos. 44. Região cortical do pedúnculo com fibras gelatinosas perivasculares (seta). 45. Polpa com grãos de amido. 46. Grãos de amido isolados dos cotilédones. 47. Idioblastos fenólicos (setas) no pedúnculo. 48. Região cortical do pedúnculo evidenciando laticíferos com conteúdo lipídico (ponta de seta) e células parenquimáticas com gotículas de lipídios (seta). (lt = laticífero). Barra = $50 \mu \mathrm{m}(44,46), 100 \mu \mathrm{m}(45,47,48)$.

Figures 44-48. Fruit of Brosimum gaudichaudii subjected to histochemical tests. 44. Cortical region of the peduncle and perivascular gelatinous fibers (arrow). 45. Pulp with starch grains. 46. Starch grains isolated from cotyledons. 47. Peduncle's phenolic idioblasts (arrows). 48. Cortical region of the peduncle showing laticifers with lipid content (arrowhead) and parenchyma cells with lipid droplets (arrow). (lt = laticifer). Bar $=50 \mu \mathrm{m}(44,46), 100 \mu \mathrm{m}(45,47,48)$. 
para a inflorescência e o fruto, evidenciando a ocorrência de fibras gelatinosas (figura 44) no pedúnculo da inflorescência e do fruto, ressaltando também a maior espessura das paredes dos laticíferos (figura 44).

O azul de bromofenol, empregado para a identificação de proteínas, mostrou reação positiva para inflorescência, fruto e semente, sendo mais evidentes no floema e laticíferos. Silva et al. (2001) relataram a ocorrência de glicídios e proteínas para os frutos de $B$. gaudichaudii. Baleroni et al. (2002), em trabalho realizado sobre a composição química de sementes de algumas espécies do cerrado, entre elas $B$. gaudichaudii, destacaram a presença de proteínas, lipídios e carboidratos, ficando acima da média quanto à concentração de amido e proteínas.

O presente estudo demonstrou que as estruturas reprodutoras de $B$. gaudichaudii são complexas e possuem características muito peculiares, distintas de outras espécies da família Moraceae descritas na literatura. Entretanto, alguns aspectos morfoanatômicos foram elucidados, tais como: presença de brácteas e bractéolas; óvulo e carpelos atrofiados; óvulo e semente unitegumentados; semente exalbuminosa; endocarpo esclerificado como camada mecânica do diásporo; a polpa, comestível quando madura, provém do receptáculo carnoso da inflorescência; abundância de laticíferos na polpa, justificando sua semelhança com a goma de mascar.

\section{Referências bibliográficas}

ALMEIDA, S.P., PROENÇA, C.E.B., SANO, S.M. \& RIBEIRO, J.F. 1998. Cerrado: espécies vegetais úteis. Embrapa-CPAC, Planaltina.

ALVES, T.M.A., SILVA, A.F., BRANDÃO, M., GRANDI, T.S.M., SMANIA, E.F.A., SMANIA JUNIOR, A. \& ZANI, C.L. 2000. Biological screening of Brazilian medicinal plants. Memórias do Instituto Oswaldo Cruz 95:367-373.

AZAMBUJA, R. 1981. The treatment of vitiligo. Brasília Médica 18:69-73.

BALERONI, C.R.S., MORAES, M.L.T., MORAES, S.M.B, SOUZA, C.S. \& SÁ, M.E. 2002. Composição química de sementes das espécies florestais mamica-de-cadela (Brosimum gaudichaudii Tréc), marolo arbóreo (Annona crassiflora Mart.), marolo rasteiro (Annona dioica St. Hil.), chichá-do-cerrado (Sterculia striata St. Hil. ex Turpin) e imbuia (Ocotea porosa (Nees) L. Barroso). Ciências Agrárias e da Saúde 2:28-32.

BARROSO, G.M, MORIM, M.P., PEIXOTO, A.L. \& ICHASO, C.L.F. 1999. Frutos e sementes: morfologia aplicada à sistemática de dicotiledôneas. UFV, Viçosa.
BARROSO, G.M., PEIXOTO, A.L., ICHASO, C.L.F., GUIMARÃES, E.F. \& COSTA, C.G. 2002. Sistemática de angiospermas. 2 ${ }^{\underline{a}}$ ed. Editora UFV, Viçosa. v.1

CARAUTA, J.P.P. \& VIANNA, M.C. 1977. Brosimum Swartz (Moraceae) do Estado do Rio de Janeiro. In Anais do XXVI Congresso Nacional de Botânica. Academia Brasileira de Ciências, Rio de Janeiro, p.75-89.

CORNER, E.J.H. 1976. The seeds of dicotyledons. Cambridge University Press, New York. v.1.

CRONQUIST, A. 1981. An integrated system of classification of flowering plants. Columbia University Press, New York.

EAMES, A.J. \& MACDANIELS, L.H. 1947. An introduction to plant anatomy. 2 ${ }^{-}$ed. Mcgraw-Hill Book Company, Inc, New York.

ESAU, K. 1965. Plant anatomy. 2a ed. Wiley \& Sons, New York.

FAHN, A. 1969. Plant anatomy. Pergamon Press, Oxford.

FERREIRA, M.B. 1973. Frutos comestíveis nativos do DF (II): gabiroba, araçás, amoreira e cajus. Cerrado 5:25-28.

FONT QUER, P. 1985. Diccionario de botánica. Editorial Labor S.A. Barcelona.

GERLACH, D. 1969. Botanische Microtechnik. George Thiem Eine Einführung, Stuttgard.

GERRITS, P.O. 1991. The application of glycol methacrylate in histotechnology: some fundamental principles. Department of Anatomy and Embryology. State University of Gröningen, Gröningen.

IAPAR - Instituto Agronômico do Paraná. 1994. Cartas climáticas do Estado do Paraná. IAPAR/SAA, Londrina.

JENSEN, W.A. 1962. Botanical histochemistry. W. H. Freeman, San Francisco.

JOHANSEN, D.A. 1940. Plant microtechnique. McGrawHill, New York.

LORENZI, H. 1998. Árvores brasileiras: manual de identificação e cultivo de plantas arbóreas nativas do Brasil. Instituto Plantarum, São Paulo. v.2.

LORENZI, H. \& MATOS, J.A. 2002. Plantas medicinais no Brasil: nativas e exóticas cultivadas. Instituto Plantarum, São Paulo.

MAACK, R. 1981. Geografia física do Estado do Paraná. José Olympio S/A, Rio de Janeiro.

MARIATH, J.E.A., SANTOS, R.P. \& BITTENCOURT JÚNIOR, N.S. 2006. Flor. In Anatomia vegetal. 2a ed. (B. Appezzato-da-Glória \& S.M. Carmello-Guerreiro, eds.). Editora UFV, Viçosa.

MARTIN, A.C. 1946. The comparative internal morphology of seeds. American Midland Naturalist 36:513-629.

MATOS, F.J.A. 1982. Aproveitamento de plantas medicinais da região do nordeste. Silvicultura em São Paulo 16A:219-225.

MAZIA, D., BREWER, P.A. \& ALFERT, M. 1953. The cytochemistry staining and measurement of protein with mercuric bromophenol blue. Biological Bulletin 104:57-67. 
MELO, J.T., SILVA, J.A., TORRES, R.A.A., SILVEIRA, C.E.S. \& CALDAS, L.S. 1998. Coleta, propagação e desenvolvimento inicial de espécies do cerrado. In Cerrado: ambiente e flora (S.M. Sano \& S.P. de Almeida, eds.). Embrapa-CPAC, Planaltina.

METCALFE, C.R. \& CHALK, L. 1950. Anatomy of the dicotyledons: leaves, stem and wood in relation to taxonomy with notes on economic uses. Claredon Press, Oxford. v.2.

O'BRIEN, T.P., FEDER, N. \& MCCULLY, M.E. 1964. Polychromatic staining of plant cell walls by toluidine blue O. Protoplasma 59:368-373.

PAVIANI, T.I. 1978. Anatomia vegetal do cerrado. Ciência e Cultura 30:1076-1086.

PIO CORRÊA, M. 1984. Dicionário das plantas úteis do Brasil e de exóticas cultivadas. Ministério da Agricultura, Rio de Janeiro. v.1.

POZETTI, G.L. 1969. Chemical study of Brosimum gaudichaudii Trecul. 1. isolation and identification of bergapten, and psoralene from the roots of Brosimum gaudichaudii Trecul. Revista da Faculdade de Farmácia e Odontologia de Araraquara 3:215-223.

POZETTI, G.L. \& BERNARDI, A.C. 1971. Chemical study of Brosimum gaudichaudii. 2. ocurrence of bergapten in fruits of Brosimum gaudichaudii. Revista da Faculdade de Farmácia e Odontologia de Araraquara 5:189-193.

ROBARDS, A.W. 1978. An introduction to techniques for scanning electron microscopy of plant cells. In Electron microscopy and cytochemistry of plant cells (J.L. Hall, ed.). Elsevier, New York.
ROMANIUC NETO, S. \& WANDERLEY, M.G.L. 1992. Flora fanerogâmica da reserva do Parque Estadual das Fontes do Ipiranga (São Paulo, Brasil): 19 - Moraceae. Hoehnea 19:165-169.

ROTH, I., 1977. Fruits of angiosperms. In Encyclopedia of plant anatomy. (K. Linsbauer, ed.) Gebruder Borntreger, Berlin. v.10.

SILVA, D.B., SILVA, J.A., JUNQUEIRA, N.T.V. \& ANDRADE, L.R.M. 2001. Frutas do cerrado. Embrapa Informação Tecnológica, Brasília.

SOLEREDER, H. 1908. Sistematic anatomy of the dicotyledons: a handbook for laboratories of pure and applied botany. Transl. by L.A. Boodle \& F.E. Fritsch. Claredon Press, Oxford. v.1.

SOUZA, L.A. 2003. Morfologia e anatomia vegetal: célula, tecidos, órgãos e plântula. Editora UEPG, Ponta Grossa.

SOUZA, L.A. \& ROSA, S.M. 2005. Morfo-anatomia do fruto em desenvolvimento de Sorocea bonplandii (Baill.) Burger, Lanjow \& Boer (Moraceae). Acta Scientiarum 27:433-438.

SOUZA, V.C. \& LORENZI, H. 2005. Botânica sistemática: guia ilustrado para identificação das famílias de angiospermas da flora brasileira, baseado em APG II. Instituto Plantarum, São Paulo.

SPJUT, R.W. 1994. A systematic treatment of fruit types. Memoirs of the New York Botanical Garden, New York. v.26.

VEENENDAAL, W.L.H.V. \& OUTER, R.W.D. 1990. Distribution and development of the non-articulated branched laticifers of Morus nigra L. (Moraceae). Acta Botanica Neerlandica 39:285-296. 
